\title{
A Protein Nanocarrier from Charge-conversion Polymer in Response to Endosomal pH
}

\author{
Yan Lee, ${ }^{a}$ Shigeto Fukushima, ${ }^{b}$ Younsoo Bae, ${ }^{a, c}$ Shigehiro Hiki, ${ }^{b, d}$ Takehiko Ishii ${ }^{e}$ and Kazunori \\ Kataoka*a,b,c,d,e
}

${ }^{\mathrm{a}}$ Division of Clinical Biotechnology, Center for Disease Biology and Integrative Medicine, University of Tokyo, Hongo 7-3-1, Bunkyo-ku, Tokyo, 113-0033, Japan. Fax: 81-3-5841-7139; Tel: 81-3-58417138

${ }^{\mathrm{b}}$ Department of Materials Engineering, University of Tokyo

${ }^{\mathrm{c}}$ Center for NonoBio Integration, University of Tokyo

${ }^{\mathrm{d}}$ CREST, Japan Science and Technology Corporation

${ }^{\mathrm{e}}$ Department of Bioengineering, University of Tokyo

E-mail: kataoka@bmw.t.u-tokyo.ac.jp 


\section{Materials and Methods}

\section{Materials}

Dimethylformamide (DMF) (Wako Pure Chemical Industries, Ltd, Japan), dichloromethane (DCM) (Wako, Japan), pyridine (Wako, Japan), and ethylenediamine (Tokyo Chemical Industry Co. Ltd, Japan) were purchased and re-distilled before use. Acetic acid and hydrochloric acid were purchased and used without further purification (Wako, Japan). Citraconic anhydride and succinic anhydride were purchased from Tokyo Chemical Industry Co. LTD. Lysozyme (chicken egg white; the optimal $\mathrm{pH}=$ 6.2) was purchased from Sigma (St. Louis, MO). Micrococcus luteus cell was purchased from Seikagaku Kogyo Co. (Japan). $\alpha$-Methoxy- $\omega$-amino poly(ethlene glycol) (molecular weight=12,000) and $\beta$-benzyl-L-aspartate- $N$-Carboxy-anhydride (BLA-NCA) were obtained from Nippon Oil and Fats Co., Ltd. (Tokyo, Japan).

\section{Synthesis}

\section{2-1. Synthesis of PEG-PBLA (PEG-poly( $\beta$-benzyl-L-aspartate)}

PEG-PBLA was prepared by the ring-opening polymerization of BLA-NCA initiated by the terminal amino group of $\alpha$-methoxy- $\omega$-amino poly(ethlene glycol). The PEG macro-initiator (500 mg; 0.0417 mmol) was dissolved in $5 \mathrm{~mL}$ of DMF/DCM (1:10). The BLA-NCA (780 mg; $3.13 \mathrm{mmol}$ ) solution in 8 $\mathrm{mL}$ of DMF/DCM (1:10) was added to the solution of PEG macro-initiator and the reaction mixture was stirred for $48 \mathrm{hr}$ at $35^{\circ} \mathrm{C}$ under argon atmosphere. The resulting polymer was precipitated into diethyl ether $(150 \mathrm{~mL})$. The crude precipitate was washed twice with diethyl ether to obtain $1.1 \mathrm{~g}$ of a white powder. Because PEG-PBLA was not so soluble in any solvent, the PEG-PBLA was converted to PEG-pAsp using $0.5 \mathrm{M} \mathrm{NaOH}$ as described in previous report (Harada, A. and Kataoka, K. J. Am. Chem. Soc. 2003, 125, 15306-15307). The GPC chromatogram of the converted PEG-pAsp was unimodal, and the $M_{\mathrm{w}} / M_{\mathrm{n}}$ were determined to be 1.01 using the calibration curve for PEG standard. 
From ${ }^{1} \mathrm{H}$ NMR measurement, the degree of polymerization (DP) of the BLA units was calculated to be 71. All the NMR spectra were recorded using a JEOL EX 300 spectrometer at $300 \mathrm{MHz}$. The chemical shifts were reported in ppm downfield from tetramethylsilane. ${ }^{1} \mathrm{H}$ NMR $\left(\mathrm{CDCl}_{3}\right): \delta 2.63-3.05(142 \mathrm{H}$, $\left.\mathrm{COCHCH}_{2} \mathrm{COOCH}_{2} \mathrm{Ph}\right), \delta 3.32\left(3 \mathrm{H}, \quad \mathrm{CH}_{3} \mathrm{OCH}_{2} \mathrm{CH}_{2}\right), \delta 3.55\left(1092 \mathrm{H}, \quad \mathrm{OCH}_{2} \mathrm{CH}_{2} \mathrm{O}\right), \delta 4.23 \quad(71 \mathrm{H}$, $\mathrm{COCHNH}), \delta 5.06\left(142 \mathrm{H}, \mathrm{COOCH}_{2} \mathrm{Ph}\right), \delta 7.20\left(355 \mathrm{H}, \mathrm{COOCH}_{2} \mathrm{Ph}\right), \delta 8.79(71 \mathrm{H}, \mathrm{COCHNH})$.

\section{2-2. Synthesis of PEG-pAsp(EDA) (PEG-poly[(2-aminoethyl)aspartamide])}

PEG-PBLA (300 mg; $0.802 \mathrm{mmol}$ of benzyl ester) was dissolved in DMF (10 mL) at $40^{\circ} \mathrm{C} .2 .7 \mathrm{~mL}$ of ethylenediamine $(40.1 \mathrm{mmol})$ was added to the solution and the reaction mixture was stirred overnight at $40^{\circ} \mathrm{C}$. The resulting solution was added dropwise into $10 \%$ aqueous acetic acid solution $(30 \mathrm{~mL})$. The neutralized solution was dialyzed against $0.01 \mathrm{M}$ hydrochloric acid solution $(\times 3)$ and distilled water $(\times 3)$. The white powder, PEG-pAsp(EDA) was obtained as hydrochloric acid salt after lyophilization. No benzyl peak was seen in ${ }^{1} \mathrm{H}$ NMR. ${ }^{1} \mathrm{H}$ NMR $\left(\mathrm{D}_{2} \mathrm{O}\right): \quad \delta 2.66 \quad(142 \mathrm{H}$, $\mathrm{COCHCH}_{2} \mathrm{CONHCH}_{2} \mathrm{CH}_{2} \mathrm{NH}_{2} \quad$ and $\left.\quad \mathrm{COCH}_{2} \mathrm{CHCONHCH}_{2} \mathrm{CH}_{2} \mathrm{NH}_{2}\right), \quad \delta 2.97 \quad(142 \mathrm{H}$, $\left.\mathrm{CONHCH}_{2} \mathrm{CH}_{2} \mathrm{NH}_{2}\right), \delta 3.23\left(71 \mathrm{H}, \mathrm{COCHCH}_{2} \mathrm{CONHCH}_{2} \mathrm{CH}_{2} \mathrm{NH}_{2}\right.$ and $\left.\mathrm{COCH}_{2} \mathrm{CHCONHCH}_{2} \mathrm{CH}_{2} \mathrm{NH}_{2}\right)$, $\delta 3.36\left(142 \mathrm{H}, \mathrm{CONHCH}_{2} \mathrm{CH}_{2} \mathrm{NH}_{2}\right), \delta 3.54\left(1092 \mathrm{H}, \mathrm{OCH}_{2} \mathrm{CH}_{2} \mathrm{O}\right)$.

2-3. Synthesis of PEG-pAsp(EDA-Cit) (PEG-poly[(N'-citraconyl-2-aminoethyl)aspartamide $]$ ) and PEG-pAsp(EDA-Suc) (PEG-poly[(N’-succinyl-2-aminoethyl)aspartamide])

PEG-pAsp(EDA) (20 mg; $0.055 \mathrm{mmol}$ of primary amine) was dissolved in pyridine (5 $\mathrm{mL})$. Citraconic anhydride $(246 \mu \mathrm{l} ; 2.76 \mathrm{mmol})$ was added dropwise into the solution and stirred overnight at $25^{\circ} \mathrm{C}$. The reaction mixture was poured into $6 \%$ of $\mathrm{NaHCO}_{3}$ solution $(30 \mathrm{~mL})$, and the mixture was purified with Amicon Ultra (MWCO=10,000; Millipore (Billerica, MA)) $\left(\times 4\right.$ with $\mathrm{NaHCO}_{3}, \times 2$ with distilled water). The final product was obtained as a white powder after lyophilyzation. The conversion yield was $87 \%$, which was calculated from ${ }^{1} \mathrm{H}$ NMR. In a manner similar to that for PEG-pAsp(EDA- 
Cit) except succinic anhydride other than citraconic anhydride, PEG-pAsp(EDA-Suc) was obtained. ${ }^{1} \mathrm{H}$ NMR of PEG-pAsp(EDA-Cit) $\quad\left(\mathrm{D}_{2} \mathrm{O}\right): \quad \delta 1.76 \quad\left(186 \mathrm{H}, \quad \mathrm{COCHCCH} \mathrm{COONa}_{3}, \quad \delta 2.64 \quad(142 \mathrm{H}\right.$, $\mathrm{COCHCH}_{2} \mathrm{CONHCH}_{2} \mathrm{CH}_{2} \mathrm{NH}$ and $\left.\mathrm{COCH}_{2} \mathrm{CHCONHCH}_{2} \mathrm{CH}_{2} \mathrm{NH}\right), \delta 3.16\left(288 \mathrm{H}, \mathrm{CONHCH}_{2} \mathrm{CH}_{2} \mathrm{NH}\right)$, $\delta 3.52\left(1092 \mathrm{H}, \mathrm{OCH}_{2} \mathrm{CH}_{2} \mathrm{O}\right), \delta 5.38-5.67\left(62 \mathrm{H}, \mathrm{COCHCCH}_{3} \mathrm{COONa}\right) .{ }^{1} \mathrm{H}$ NMR of PEG-pAsp(EDASuc) $\left(\mathrm{D}_{2} \mathrm{O}\right): \delta 2.25\left(142 \mathrm{H}, \mathrm{COCH}_{2} \mathrm{CH}_{2} \mathrm{COONa}\right), \delta 2.57\left(142 \mathrm{H}, \mathrm{COCHCH}_{2} \mathrm{CONHCH}_{2} \mathrm{CH}_{2} \mathrm{NH}\right.$ and $\left.\mathrm{COCH}_{2} \mathrm{CHCONHCH}_{2} \mathrm{CH}_{2} \mathrm{NH}\right), \delta 3.10\left(142 \mathrm{H}, \mathrm{COCH}_{2} \mathrm{CH}_{2} \mathrm{COONa}\right), \delta 3.15\left(288 \mathrm{H}, \mathrm{CONHCH}_{2} \mathrm{CH}_{2} \mathrm{NH}\right)$, $\delta 3.51\left(1092 \mathrm{H}, \mathrm{OCH}_{2} \mathrm{CH}_{2} \mathrm{O}\right)$.

3. Degradation of citraconic amide in the block copolymer

The degradation of citraconic amide was measured by the fluorescamine method. Fluorescamine is an amine-reactive fluorescence dye with the maximum fluorescence wavelength of $465 \mathrm{~nm}$. Because the primary amine of ethylenediamine group was exposed after the degradation of citraconic aminde in the block copolymer, the degradation percentage could be calculated from the comparison of the fluorescence before and after the incubation. Nanodrop ${ }^{\circledR}$ ND-3300 fluorospectrometer (NanoDrop Technologies; Wilmington, DE) was used for the analysis.

Each sample of the block copolymers was dissolved in distilled water at the concentration of about 1 $\mathrm{mg} / \mathrm{mL} .100 \mu \mathrm{L}$ of this stock solution was mixed with $100 \mu \mathrm{L}$ of $\mathrm{pH} 5.5$ acetate buffer $(10 \mathrm{mM})($ or $\mathrm{pH}$ 7.4 phosphate buffer $(10 \mathrm{mM}))$. This solution was incubated at various temperatures $\left(4^{\circ} \mathrm{C}, 25^{\circ} \mathrm{C}\right.$, and $\left.37^{\circ} \mathrm{C}\right)$ and $10 \mu \mathrm{L}$ of each sample was diluted into $100 \mu \mathrm{L}$ of $\mathrm{pH} 9.1$ borate buffer $(0.1 \mathrm{M})$ every hour. This mixture was added by $10 \mu \mathrm{L}$ of fluorescamine solution in DMF ( $2 \mathrm{mg} / \mathrm{mL})$ and incubated at room temperature for $10 \mathrm{~min}$. Its fluorescence was measured at the emission wavelength of $465 \mathrm{~nm}$. The excitation light source is UV light $(365 \mathrm{~nm}-400 \mathrm{~nm})$ of the Nanodrop ${ }^{\circledR}$ ND-3300 fluorospectrometer.

$100 \%$ of exposed amine was calculated from the fluorescence of the sample after the incubation of block copolymer in $0.01 \mathrm{M} \mathrm{HCl}$ overnight and $0 \%$ was from that of the fluorescence of blank buffer solution, as a negative control. 
4. Temperature dependence of the degradation

The degradation of the citraconic amide at three temperature points $\left(4^{\circ} \mathrm{C}, 25^{\circ} \mathrm{C}\right.$, and $\left.37^{\circ} \mathrm{C}\right)$ was measured. The degradation at $37^{\circ} \mathrm{C}$ was shown in Fig. 1 and the others are shown in Fig. S1 below.
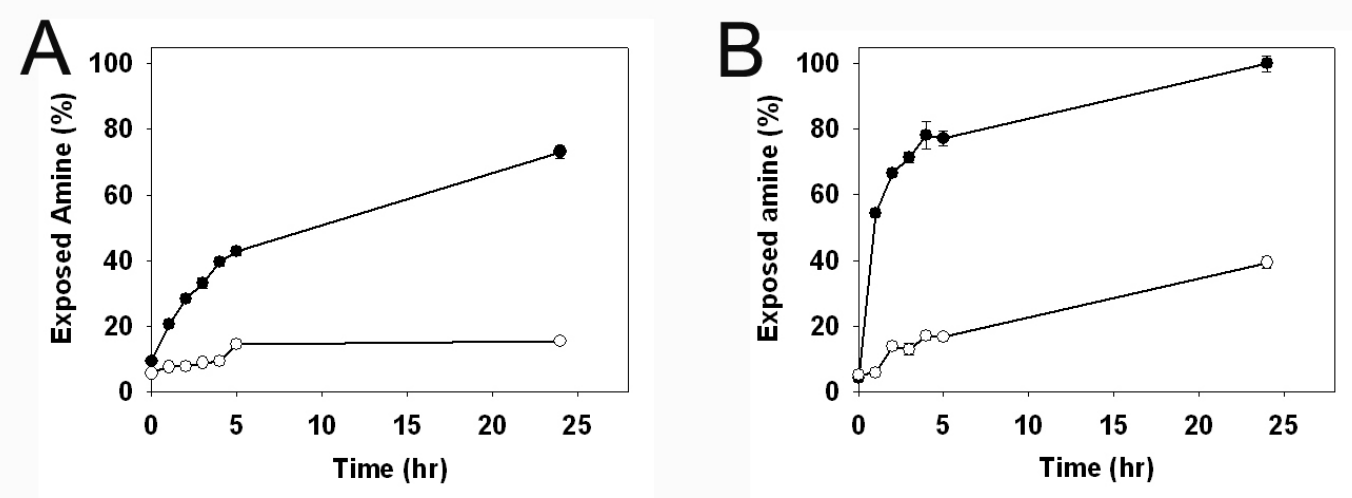

Fig S1. The citraconic amide degradation at $4^{\circ} \mathrm{C}(\mathrm{A})$ and $25^{\circ} \mathrm{C}(\mathrm{B})$. The black dots $(\bullet)$ represents the degradation at $\mathrm{pH} 5.5$ and the white dots $(\circ)$ does at $\mathrm{pH} 7.4$.

5. The analysis of the formation and dissociation of the PIC micelles between the block copolymer and lysozyme

Each of lysozyme $(1.00 \mathrm{mg} / \mathrm{mL})$ and PEG-pAsp(EDA-Cit) $(0.550 \mathrm{mg} / \mathrm{mL})$ was dissolved in distilled water. Because lysozyme has 11 arginine and 6 lysine residues and molecular weight of 14300, the arginine or lysine density is one residue per 841 Da. Similarly, the carboxylate density of PEGpAsp(EDA-Cit) is one per $460 \mathrm{Da}$. Therefore, if we mixed equal volume of two solutions mentioned above, the ratio of the charged group was 1.

After each solution was filtered through $0.1 \mu \mathrm{m}$ syringe filter, equal volumes $(0.3 \mathrm{~mL})$ of two solutions were mixed each other. The mixture was stabilized at $4^{\circ} \mathrm{C}$ for $1 \mathrm{hr}$, and diluted with $1.8 \mathrm{~mL}$ of the acetate buffer $(\mathrm{pH} 5.5,10 \mathrm{mM}$, no $\mathrm{NaCl})$ or the phosphate buffer $(\mathrm{pH} 7.4,10 \mathrm{mM}$, no $\mathrm{NaCl})$. The final lysozyme concentration was $0.125 \mathrm{mg} / \mathrm{mL}$. Each sample was incubated at various temperatures 
$\left(4^{\circ} \mathrm{C}, 25^{\circ} \mathrm{C}\right.$, and $37^{\circ} \mathrm{C}$ ). All DLS measurements were reported using Zetasizer Nano-ZS (green badge, ZEN3500, Malvern, Ltd. Malvern, U. K.) with a green laser of $532 \mathrm{~nm}$.

6. Temperature dependence of the formation and dissociation of the PIC micelles

The time course of the mean diameter of the PIC micelles at $37^{\circ} \mathrm{C}$ was shown in Fig. 2B and Fig. 2C. The others are shown in Fig. S2 below.

The stabilized diameter of the PIC micelles at $\mathrm{pH} 7.4$ was different at each temperature. At $4^{\circ} \mathrm{C}$, it was about $80 \mathrm{~nm}$ without much increase from the initial size. However, the size was $100 \mathrm{~nm}$ at $25^{\circ} \mathrm{C}$ and $130 \mathrm{~nm}$ at $37^{\circ} \mathrm{C}$ (Figure $2 \mathrm{~B}$ ). These phenomena are probably due to the difference between the micelle-forming temperature and the incubation temperature. We had formed the micelles at $4^{\circ} \mathrm{C}$ and incubated them at $25^{\circ} \mathrm{C}$ or $37^{\circ} \mathrm{C}$. The size and the association number of the PIC micelles are dependent upon temperature, so that the change of temperature can induce the change of the micelle size. Therefore, the size increase at $\mathrm{pH} 5.5$ was resulted from both degradation of the citraconic amide and temperature increase.
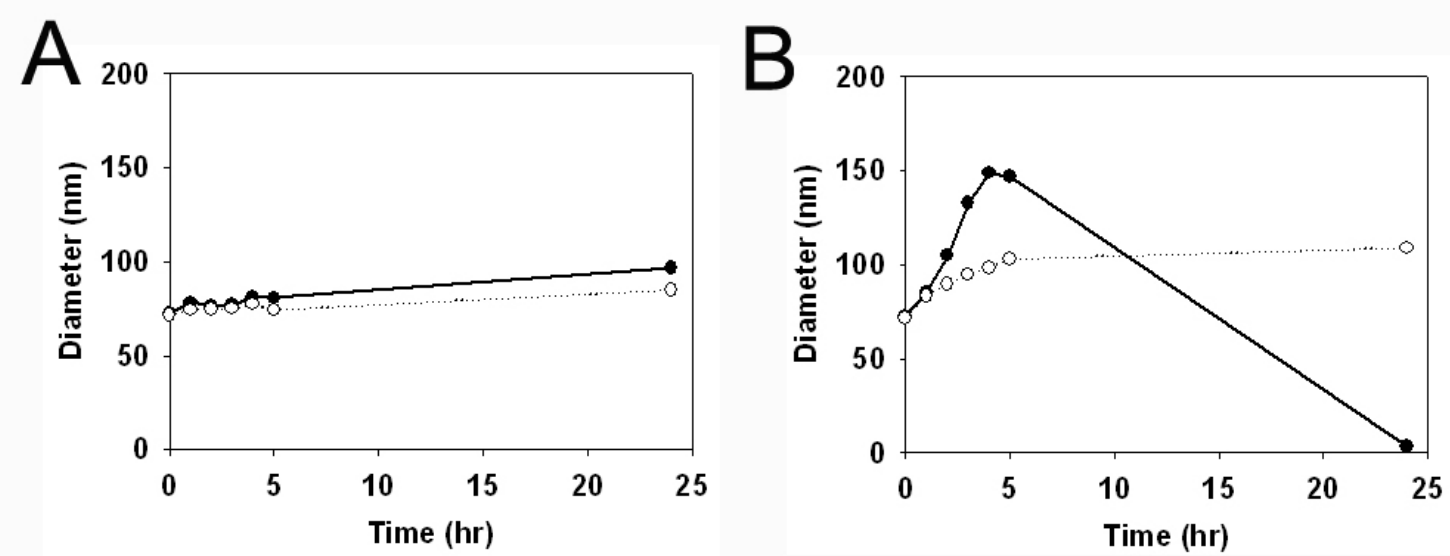

Fig S2. Time course of the diameter of the PIC micelles between PEG-pAsp(EDA-Cit) and lysozyme at $4^{\circ} \mathrm{C}(\mathrm{A})$ and $25^{\circ} \mathrm{C}(\mathrm{B})$. The black dots $(\bullet)$ represents the diameters at $\mathrm{pH} 5.5$ and the white dots (o) does at $\mathrm{pH} 7.4$.

7. Lysozyme activity measurement 
The measurement of lysozyme activity was performed by the method of the previous paper in this laboratory (Harada, A. and Kataoka, K., J. Am. Chem. Soc. 1999, 121, 9241-9242). The lysozyme ativity is related to the increase of transmittance $(450 \mathrm{~nm})$ of the solution of Micrococcus luteus cells. The specific activity of lysozyme is:

$$
\text { Specific activity }(\text { units } / m g)=\Delta a \times \frac{1000}{D \times 10} \times \frac{1}{f}
$$

where $\mathrm{D}$ is $\mathrm{mg}$ of lysozyme/1 $\mathrm{mL}$ of reaction, $f$ is the factor of ML cells, and $\Delta \mathrm{a}$ is the change of absorbance (at $\left.35^{\circ} \mathrm{C}\right)$.

After swelling of ML cells in distilled water at $4{ }^{\circ} \mathrm{C}$ overnight, the stock solution of the cells was prepared so as to have the transmittance at $450 \mathrm{~nm}$ (T\%) of 20-30\% after the 5-fold dilution. (The transmittance was measured using V-550 UV/vis Jasco spectrophotometer).

The PIC micelles between PEG-pAsp(EDA-Cit) and lysozyme were prepared by the method mentioned above. The micelles were incubated in two buffer solutions (acetate buffer ( $\mathrm{pH} 5.5 ; 5 \mathrm{mM})$; phosphate buffer $(\mathrm{pH} 7.4 ; 5 \mathrm{mM}))$ at $37^{\circ} \mathrm{C}$. The lysozyme activity of the solutions was measured every hour.

Lysozyme activity was expressed as the relative activity. It was the ratio of the activity in the micelles solution to the activity in the positive control solution which had been prepared with the same mass of lysozyme as that in the PIC micelle solution.

After $1.2 \mathrm{~mL}$ of the sample solution was mixed with $0.3 \mathrm{ml}$ of ML cell stock solution, the time course of the transmittance at $450 \mathrm{~nm}$ was measured immediately at $35^{\circ} \mathrm{C}$. The absorbance variation for the first 1 minute was used for the calculation of the relative activity. The relative activity is:

$$
\text { Relative activity }(\%)=\frac{\Delta a(\text { sample solution })}{\Delta a(\text { control solution })}
$$

